\title{
MEDIEVAL REPRESENTATION OF THE LEGEND OF SAINT LADISLAUS IN COMITATUS GÖMÖR
}

The art history, restoration and historical research of the last decades enriched our knowledge of the cult, iconography, and representations of St. Ladislaus with numerous so far unknown data and portrayals. Through the collaboration of various disciplines, lots of studies, analyzes, and books were published that attempt to interpret this composite pictorial representation, which can only be found in the Carpathian Basin and reveal the great, living cult of our king, Saint Ladislaus on the territory of the $\mathrm{I} 4-\mathrm{I} 5^{\text {th }}$ century Hungary.

A prominent group representing the legend of Saint Ladislaus can still to be found on the walls of medieval churches in Comitatus Gömör. From the second half of the 2oth century, art history research ${ }^{\mathrm{I}}$ is showing a strong interest in mural paintings, since the complex, well preserved cycles, similar to the ones in Gömör are of great importance for the special and unique representation of the legend. In addition to the mural paintings in the medieval churches of Karaszkó (Kraskovo), Rimabánya (Rimavská Baňa), and Rákos (Rákoš) settlements ${ }^{2}$, in 2017 the Gömör cycles were expanded with two new representations. Due to the fragmentary nature of the mural paintings found in the churches of Kövi (Kameňany) and Szilice (Silica), they do not allow an in-depth art history study, but because of their location and connection to the larger, more complete mural painting cycles, they are extremely significant. The purpose of this study is to reinterpret the frescoes of Saint Ladislaus legends in Comitatus Gömör in the light of recent research, complemented with two new discoveries that hopefully will help in the accurate dating of the mural paintings and in the examination of their creation.

\footnotetext{
* Eva Szakalos - doktor, pracownik Chrześcijańskiego Muzeum w Ostrzychomiu, specjalizuje się w zakresie historii sztuki średniowiecznej i nowożytnej.

1 V. Dvořáková, J. Krása, K.Stejskal, Stredoveká nástenná malba na Slovensku, Praha-Bartislava 1978; M. Togner, Stredoveká nástenná malba v Gemeri, Bratislava 1988, pp. 33, 120; Idem, Stredoveká nástenná malba na Slovensku, Bratislava 1988, pp. 8, 13; Zs. Lukács, A Szent László-legenda a középkori magyar falképfestészetben, In: Athleta Patriae. Tanulmányok Szent László történetéhez, Budapest, 1980, pp. 163-204; Gy. László, Szent László középkori falképei, Budapest 1993., I. Gerat, Narativny cyklus zo života sv. Ladislava vikonografickom programe gemerskych kostolov, Ars 1,1996, pp. 11-56.

2 M. Prokopp, Középkori freskók Gömörben. Méry Ratio, Somorja 2007, pp. 22-26; 52-64; V. Plekanec, T. Haviar, Gotický Gemer a Malohont. Italianizmy v stredovekej nástennej malbe. Arte Libris, Bratislava 2007, pp. 48-66; $134-160 ; 172-185$.
} 


\section{"Picture and Text" - The pictorial representation and written sources of the legend of Saint Ladislaus}

The churches of historical Hungary, including Comitatus Gömör, display a special event of Saint Ladislaus's life - the battle of Kerlés and the related story of rescuing a girl. The battle is a real historical event in which Prince Ladislaus together with King Solomon and Prince Géza had defeated the Cumans, who were invading the territory of the Hungarian Kingdom in I0683. There is a story linked to the battle in which a Cuman leader captures a beautiful Hungarian girl. Then Prince László, heroically, without fear, defeats the pagan and saves the girl. This was a legend commonly known in the Middle Ages. In addition to the announcements in the preaching, it can also be found in the nave of the churches and, from the I3th till the I5th century, the mural painting cycles have authentically restored this tradition ${ }^{4}$.

The text version of the legend is known from several sources. The best known is the description in the Illustrated Chronicle ${ }^{5}$, with several details similar to the German chronicle of Henrik Müngeln ${ }^{6}$. In addition to the written sources, we can also find the depiction of the legend in the miniature paintings, thus beyond the miniatures of the Illustrated Chronicle, the sequence of the Vatican Legendarium is also significant, which essentially follows the iconography of the mural paintings 7 . The mix of folk tradition and the variations of written and represented legend leads to different versions, and this legend with a high degree of detail was placed on the walls of the churches ${ }^{8}$.

The most complex and most impressive versions of the legend can be found in the churches of Karaszkó, Rimabánya, and Rákos. On the wall of the naves, there is a large representation from the scene of the "Exodus" up to the meticulous representation of the "Relaxation", which fills the full upper bar of the northern wall. In the case of the first two churches, the mural paintings were preserved almost completely intact, so they can be thoroughly inspected in detail. The legend depiction of the Church of Rákos is somewhat fragmented, but the central motif can be easily identified. The last scenes of the legend have been lost, so we cannot identify them accurately.

\section{"Mural painting and the Customer" Karaszkó}

The mural painting showing the event of the battle of Keres begins with the representation of the Castle scene. Ladislaus and his troops are leaving Várad, the citizens of the castle are biding them farewell, blowing the trumpet from the windows of the three-towered castle, surrounded by the wall, letting the armed forces leave to fight. The lower part of the image is broken off, so the scene cannot be fully examined. A unique feature of the depiction is the young noble, leaving the gate in a fancy dress, behind the army, holding a mace in his hand. The young noble man sitting on the horse is an integral part of the scene, but he is difficult to identify. Neither the written sources nor the other variants of the legend refer

\footnotetext{
Zs. Lukács, A Szent László-legenda..., p. 163.

Ibidem, pp. 163-164.

Képes Krónika, II. kötet. Budapest 1964. 124-125.

6 E. Szentpétery, Scriptores rerum Hungaricum tempore ducum regumque stirpis Arpadianae gestarum, Vol.2., Budapest 1938. 177.

7 Zs. Lukács, A Szent László-legenda..., p. 164-171.

8 I. Gerat, Naratívny cyklus zo života sv. Ladislava ..., pp. 12-16.
} 
to him, so the only option is that he was depicted at the customer's request. The next scene of the legend is the Battle scene, which depicts the battle of the Cumans and Hungarians. This scene is the most prominent part of the representation. The Hungarian army led by King Ladislaus - wearing the crown - is chasing the Cuman troops. The composition of the soldiers in the fresco is very thorough. The Hungarian cavalry, in full plate and chainmail armor, with maces, swords, spears and shields, is confidently chasing the Cuman troops, who are fleeing on their horses while shooting the arrows backwards. Ladislaus, on his legendary horse called Nail' , leading the army, tries to reach the leader of the Cumans with his spear, but he is not fast enough to catch and stab his opponent. The next scene depicts the melee combat of Ladislaus and the Cuman. The painter depicts two equal opponents on the mural painting called "Wrestling". Their hands on one another's shoulders, trying to defeat the opponent, but as the legend's written version notes, they are equally balanced in power and only with external help can Ladislaus rise above the Cuman. The external aid, in this case, is the abducted girl, who strikes the Cuman down with Ladislaus's hatchet, cutting his leg. The Wrestling scene is followed by the Beheading depiction. On the mural painting, Ladislaus is holding the laying pagan by his hair, and the rescued girl strikes the enemy down with the hero king's sword. The last, final scene of the story is not mentioned in any written source. The illustration of the Relaxation scene is what makes the whole cycle truly mesmerizing. The hero, who is tired after the battle, bends his head to sleep in the lap of the resting girl, under the tree. His crown, shield, and armor gloves rest on the branch of the tree, highlighting his unconditional confidence towards the rescued girl. The monumentality of the mural paintings of Saint Ladislaus's legend immediately catches the attention of the people entering the church's nave. The artist who painted these mural paintings had excellent qualities; powerful artistic expression is presented through his work. The exact structure of the scenes, their classical and individual figures as well as the dramatic representation, makes the artist stand out from the classic Gömör wall painters, and shows a new, fresh direction in such paintings ${ }^{10}$.

\section{Rimabánya}

The scenes of the Saint Ladislaus's legend on the northern wall of Rimabánya's church are in the exact same order as those of the Karaszkó portraits, but the creation of the scenes, the design, and the compositions are largely different from those of Karaszkó. In the scene of the Exodus, there is also a robust, multi-tower, fortified castle in the center. The elaboration of the building is more meticulous, the members of the castle can be seen among the parts of the building, and a figure standing in the tower blows the trumpet. The damaged lower part of the Karaszkó scene is not left in its entirety, but in its contours, there is a figure crouching at the base of the castle wall with a high cap on its head, like the ones the Cumans have. The identification of the figure is cumbersome in the given scene, as analogies are not available regarding the shape ${ }^{\text {II }}$ The Battle scene, similarly to the Karaszkó mural painting, is the most prominent part of the legend. A monumental scene unfolds on the northern wall of the nave. At first, the multitude of horses and warriors may seem chaotic, however,

\footnotetext{
9 Képes Krónika, op.cit., p. 124-125.

10 M. Prokopp, Középkori freskók Gömörben ..., pp. 54-55.

11 I. Gerat, Naratívny cyklus zo života sv. Ladislava ..., p. 37.
} 
contemplating the scene for longer time reveals, that the painter deployed his figures in disciplined, regular order. Ladislaus's figure is located at the center, and one of the main elements of the realistic scene is him treading on the body parts of dead warriors with his horse. The peculiarity of the representation is the large sized shape of a woman between the walls of Várad and the withdrawing armies. The figure is certainly not the kidnapped girl, as we first thought - it is clearly visible that she is wearing a completely different dress than the girl seen in other scenes, besides, her figure almost gets a special, priority place on the representation ${ }^{12}$. We can observe that it occupies the same place as the unidentified noble youth on the mural painting in Karaszkó. The question arises, in this case whether the client or the person associated with the client had been painted in this part of the legend. The two representations, the Wrestling and the Beheading depiction following the Battle scene are at the edge of the wall zone. The Exodus and the Battle scene are displayed as a large, meticulously elaborated section, compared to these the fight of Ladislaus, the girl and the Cuman look small. Each element of the story in their structure follows the events of the mural painting in Karaszkó exactly. The last scene of the legend, the depiction of the Rest, did not fit onto the northern wall of the nave, so it was placed on the eastern wall. The scene is damaged, but the elements are still clearly visible. The warrior resting in the girl's lap, his shield also placed by the tree, but beside it, there is a red dress like the one the defeated Cuman had. According to Ivan Gera's observations, it is certainly the garment of the defeated opponent. But why was it taken off his dead body and why was it placed on the tree? None of the sources explain that ${ }^{13}$.

\section{Rákos}

There is a village, a little further away from the Rima valley, near the Turóc stream. This village has a church which dates to the I4th century and art history research has shown a great concern in this church for a long time now. The mural paintings of the churches discussed so far occupied a central place in the nave. Those who enter through the southern main portal are welcomed by the monumental, large portrayal of Saint Ladislaus's legend. In the nave of the church of Rákos, the legend is located on the northern wall, it still occupies only a secondary place in the series of mural paintings. The scene looks small besides the Last Judgment depiction on the northern wall. The legend had been added to the upper, barely visible zone of the northern wall of the church's nave as an addition, or it can be interpreted as a fashionable trend associated with that age. However, when we begin to interpret the church's mural paintings and their program, the idea of fashion and customs can immediately be abandoned. In the case of the church of Rákos, it is apparent at first sight, that here is a very serious, conceptual program, which rests on deep, thoughtful theological foundations ${ }^{14}$. Part of this program is the Saint Ladislaus legend seen on the northern wall. Although the legend is damaged, the main scenes are still clearly visible and interpretable. The mural painting of Rákos starts with the Exodus and the Battle scene, but here we cannot see a classically fortified castle with turrets and inhabitants, only a rocky fortress from

\footnotetext{
12 Ibidem, pp. 36-36.

13 Ibidem, p. 38.

14 Prokopp, 2010. 22-26.
} 
where Ladislaus's army goes to battle. The hero knight stands in the middle of the picture, well-recognizable by his light-colored horse and the glory around his head, wearing a helmet instead of a crown. In this case, it was not important to emphasize his royal personality, but to appear as a hero warrior, the pagan conqueror. The central element of the Battle scene is also an extraordinary and unique motif, which has not been published so far, neither in known text nor in pictorial representations. Ladislaus sitting on his horse, with one hand pulling down the Cuman leader, who is wearing a green robe, from his horse and with his other hand he is about to strike down with his hatchet. In front of the Cuman leader, we see his comrades, as they are in their usual form, sitting on horses, turned backwards, shooting arrows at the army following them. In the foreground of the depiction, there is a white, wounded horse lying, in front of it, there is a brown horse, which is about to trip up with a helpless, perhaps dead figure on its back. From an iconographic point of view, the subsequent scene is also special. The cruel battle continues, within which one of the Hungarian warriors, whom we saw at the Exodus scene, comes forth and strikes down onto the head of the Cuman, who was almost completely pulled off his horse by Ladislaus before. In front of him, there is a ripped off hand and a thrown saber. The remaining part of the legend is heavily damaged, so the figure of Ladislaus and probably the scene of the Wrestling is just barely visible. It is unfortunate that the rest of the legend has not survived, since we can see in the introductory episode that in this case we can talk about a special representation. The space left for the ending scenes of the legend is very small, therefore it is not possible to assume there was a detailed Beheading and a Relaxation scene. In addition, the girl's complete absence is very prominent, as she does not appear even in the Wrestling scene. Apparently, in the case of the mural painting of Rákos, the emphasis was neither on the abduction of the innocent girl nor on her rescue. What had major importance was the victory over the evil, the pagan. The large-scale Last Judgment scene underneath the wall underlines this theory, in which the good ones are rewarded, and Christ is ultimately victorious over the evil.

In the case of the Gömör mural paintings, the contrast between the two mural painting types is interesting and conspicuous. The reason for this is probably to be found among the customers. In the case of the Rima Valley mural paintings, Karaszkó and Rimabánya, it is clear that the emphasis was placed on the figure of king Ladislaus, the hero, the leader, who defeats his opponent (meanwhile he does not become a murderer, so his moral victory is not questionable), saves the girl, and for his actions receives a reward. A wonderful sequence, its religious dimension is indisputable, but also in a profane sense, it becomes the main bastion of knightly culture and knightly ideal on the walls of the churches. For the customers of the mural paintings, in the case of the two churches, we certainly must look among lords, faithful to knightly and royal ideas. In the I4th century, Tamás Szécsényi from the Kacsics family became the lord of Rimabánya and Karaszkó ${ }^{15}$. He has acquired enormous wealth and has held many position ${ }^{16}$. He founded the prestige of his family, and later his son Miklós Kónya (Szécsényi) became the owner of the land. Among the Szécsényi’s, Kónya warden's son, Frank and his brother Simon got the land. Frank Szécsényi, as loyal follower and supporter of Zsigmond Luxemburg, had become the owner of priority titles and lands. He had several functions as a bailiff and a castellan and above that he also served as a judge

15 M. Prokopp, Középkori freskók Gömörben..., p. 52.

16 C. Tóth, Luxemburgi Zsigmond uralkodása 1387-1437. Kossuth kiadó zRt., 2009, pp. 21-28. 
of the "Jász" ${ }^{17}$ From 1393 to I395, he was the voivode of Transylvania, and eventually from I397 to I408, until his death, Lord Chief Justice. He can be found in a diploma from I388 by the title of nobility Hollókő, at this time he was the bailiff of Nógrád. His close relationship with the king is listed also in contemporary diplomas. One of the most eloquent of these documents, concerning the Rima Valley comes from the Hanvay family archives, dated 8th of October 1387. This document notes that on the day of Gál (I6th of October), the king and the queen were in Rimaszombat ${ }^{18}$. Not long after the crowning of Zsigmond Luxemburg, in August, he and his wife, Queen Mary, went to Várad, touching Vác, Nagyhatva, and Debrecen. Then, they spent a few days in Diósgyör, in Mary's favorite location. The sources record three more stops before returning to $\mathrm{Buda}^{19}$. One of the stops is the already mentioned Rimaszombat, where they have been invited, most probably by Frank Szécsényi, the king's loyal man. From there, they went on to the castle of Zólyom, and before the arrival to Buda they stayed for a few days in Visegrád ${ }^{20}$. From the problem's perspective, I have examined the visit of Zsigmond Luxemburg in Rimaszombat as it is extremely important. The relationship, between the Szécsényi family and Zsigmond Luxemburg has already been noticed by the research of the first studies about the mural paintings. In fact, it highlights that their loyalty to the king, as well as Zsigmond's absolute respect for Saint Ladislaus's figure, could have led to the creation of the paintings ${ }^{21}$. This is supported by the king's visit to Rimaszombat, in connection with this it is easy to imagine, that Zsigmond could have visited Frank Szécsényi's other properties, like Rimabánya or Karaszkó as well. However, if the king has not even stopped at the specific locations, his coming could have been preceded by great preparations, and presumably the large-scale mural paintings could have been prepared in his honor, certainly before 1387.

\section{"Rész és egész" - Újonnan felfedezett falképek Gömörben}

20I7-ben a gömöri Szent László legendák sora két új falképpel bővült. A Kövi és Szilice települések templomaiban folyó falképfeltárások eredményeképp két, nagyon sérült, de azonosítható jelentre bukkantak a kutatók. A két templom falképeivel mindeddig a kutatás nem foglalkozott behatóbban, így a templomokat borító teljes falképegyüttesek és a történeti kontextus bemutatására e tanulmány keretein belül csak érintőlegesen vállalkozok ${ }^{22}$.

\section{"Part and Complete" - Newly Discovered wall paintings in Gömör}

In 20I7, the series of St. Ladislaus legends in Gömör expanded with two new mural paintings. In the churches of Kövi and Szilice, as a result of mural painting exploration, researchers found two very damaged but identifiable scenes. Up until now, the mural painting research

\footnotetext{
17 P. Engel, Magyarország világi archontológiája 1301-1457 II. kötet, MTA Történettudományi Intézete, Budapest, 1996, p. 221.

18 Hanvay család levéltára (Q 86) - Okl. 56925; 1384-05-21

19 C. Tóth, Luxemburgi Zsigmond..., p. 23.

20 E. Mályusz, Zsigmondkori oklevéltár I. (1387-1399) Magyar Országos Levéltár kiadványai, II. Forráskiadványok 1, Budapest 1951, pp. 26., 267.

21 M. Prokopp, Középkori freskók Gömörben..., p. 52.

22 V. Plekanec, T. Haviar, Gotický Gemer a Malohont..., p. 180.
} 
of the two churches has not been thoroughly handled, so within the framework of this study, I can undertake only tangentially the presentation of the complete mural artwork surrounding the churches and its historical context.

\section{Kövi (Kameňany)}

The settlement was of great importance in the area, already in the izth century. The sources note that from the second half of the I8th century, the settlement belonging to the landowners had all the rights, and Szár (Tar) Detre wanted to make this settlement the center of his estate. Certainly, this endeavor of his relates to the construction of the Castle of Kövi. In 1358, the land belonging to Kövi was in the possession of Péter Csetneki ${ }^{23}$. The settlement, however did not develop into a city, because its great impetus, in the beginning of the I5th century, was interrupted by the discordance of the Bebek's and the Csetneki's ${ }^{24}$. According to the sources, Rákos also belongs within the borders of Kövi ${ }^{25}$. In I427, the area was registered as the property of the Bebek and Csetneki family, but after the death of János Csetneki II, it was under the jurisdiction of Miklós Bebek Pelsőci. Thus, based on the source already mentioned, it can be assumed that in the I6th century Rákos was also in the possession of the Csetneki family.

For further research, the aforementioned data can supply a novel and special starting point. First of all, because the mural paintings in Rákos have so far been a kind of separate unit, with nothing to relate to in the area. In 20II, however, this trend seemed to collapse, as research explored new high-quality mural paintings in the church of Kövi, near Rákos. As a result of this ongoing research, what certainly is a fragment of the Saint Ladislaus legend originally displayed in the entire upper bar of the wall was discovered in 2017 on the northern wall of the nave. On the fragmentary representation, there is a figure sitting on a horse with a high cap on his head, shooting an arrow in a twisted position. On the side of the figure, there is a quiver, behind it, there is an armored knight who is about to strike him down with his sword. The depiction is very fragmentary, but without a doubt it is part of the legend. Unfortunately, the northern wall was broken through by a baroque window, so we cannot hope for a complete legend to be found even by further explorations, but after the expected restoration we will probably see much more of the depicted portraits. Additionally, further explorations might bring new results, so the iconography of the frescoes, decorating the church, the various master groups and the individual epochs might also be identified later.

\section{Szilice (Silica)}

The area was probably owned by the bailiff Tekus, already in the 13 th centur $y^{26}$. In the land division process of I340, the settlement is mentioned separately, and in the sources, we can

\footnotetext{
23 I. Nagy, Anjoukori okmánytár. Codex diplomaticus Hungaricus Andegavensis. VII. (1358. jan. 1.-1359. márcz. 31.), Budapest 1920.

${ }^{24}$ B. Ila, Gömör megye II. Magyarság és nemzetiség, tanulmányok a magyar népiségtörténet köréböl. MTA., Budapest 1944, pp. 540-541.

25 Idem, Gömör megye III. Magyarság és nemzetiség, tanulmányok a magyar népiségtörténet köréböl. MTA., Budapest, 1946, p. 250.

${ }^{26}$ Gy.Dénes, A Bódvaszilasi medence 700 éves története. Borsodi kismonográfíák 16. Herman Ottó Múzeum, Miskolc, 1983, p. 45.
} 
find Szilice's name among the estates belonging to the Szalonnai branch ${ }^{27}$. Next, the settlement is mentioned in I399, when the properties of István Szalonnai and his family were recorded. The diploma does not only list the family's estates covering I8 villages, but also the buildings, one by one ${ }^{28}$. In the 15 th century, the Csetneki family put their hand on some of the Szalonnai family's estate. Particularly interesting is that according to the records, at the beginning of the I8th century the Szalonnai family may have already been in contact with the Csetneki's, who dominated the neighboring estates, since László Csetneki's wife was certainly Ilona, the daughter of István Szalonnai ${ }^{29}$.

The excavation of the mural paintings took place in 2013, in the church of Szilice ${ }^{30}$. Until now, the research did not handle the identification of the frescos. The remaining mural paintings are fragmentary, it is very difficult to identify the individual scenes and also the individual, well-visible layers. The representation of the Saint Ladislaus legend can now be identified only from pieces. Certainly, it must have been created in the first phase of painting the church. It can be found in the upper lane of the nave's northern wall. The hoofs of the horses and some pieces of the trappings are clearly visible on the surviving fragments. On the next wall section, the fragmentary shape of two figures can be seen. One of them has his left foot on the right foot of the figure behind him, who is wearing a long tunic and has a sabre by his left foot. This is beyond any doubt the scene of the Saint Ladislaus Legend, in which the attack of the girl interrupts the fight of the two parties. The dating of the scene is also questionable. Considering the mural paintings in Gömör with the same theme, it could have been made in the second half of ther4th or in the first half of the I5th century, ordered by the Szalonnai family ${ }^{31}$.

Considering the mural paintings in Szilice, the scene that has been partially preserved in a decorative frame can be classified as the second phase of the painting, which is visible under the legend. At the top of the given scene, three shapes can be identified, all three depicted with glories and sentence ribbons, the right figure with tonsure. The style in which the figures were painted, the sentence ribbons and the decorative frame can be found in the headquarters of the Szalonnai family, in the medieval church of Szalonna. Now it is lost but in the records of the excavations, it can be red that the legend of Saint Ladislaus has been found on the northern wall of the church of Szalonna, which brings the Gömör portraits and the wonderful portraits of the church of Szalona even closer. This can be an important clue for further research aimed at identifying the remaining wall paintings of the church of Szilice.

The primary purpose of my study was to rediscover the outstanding and unique mural paintings of Comitatus Gömör and put them in the center of attention. The monumental legend depictions of Rimabánya and Karaszko still astonish and amaze people entering the churches, and the interpretation of the mural paintings in Gömörrákos means a continuous problem

\footnotetext{
27 G.Fejér, Codex diplomaticus Hungariae ecclesiasticus ac civilis. Tomi VIII., Vol. 4., Budae 1832 p. 467.

28 Mályusz, Zsigmondkori oklevéltár I. (1387-1399)..., pp. 677-679.

29 I. Nagy, Magyarország családai czímerekkel és nemzedékrendi táblákkal. Beimel és Kozma, Pest. 1857-1868. 30 .

30 P. Gomboš, P.Tajkov, Kostol reformovanej cirkvi v Silici vo svetle najnovšich výskumov, „Východoslovenský pravek X" 2013, pp. 237 - 244.

31 Z.Magyar, Abaúj - Torna megye Szent László - falképei. Herman Ottó Múzeum évkönyve 33-34, Miskolc 1996, p. 583; T. Kerny, Keresztény lovagoknak oszlopa, In: Gy László, T. Kerny, A Szent László-legenda középkori falképei, Budapest 1993, p. 212.
} 
for both the laics and the professionals. In the decades of research and experimenting with the interpretation of mural paintings, new discoveries can open new doors that brings us closer to understanding and interpreting the miraculous cycles. Based on the newly-acquired representations of Kövi and Szilice, it is obvious that the subject is much more complex and more diverse than we previously thought. We hope that this region will enrich the series of Central European monuments and mural paintings with such wonderful discoveries in the future as well.

\section{Medieval Representation of the Legend of Saint Ladislaus in Comitatus Gomor Summary}

The aim of the article is to carry out detailed analysis of the frescoes of Saint Ladislaus legend in comitatus Gomor. Basing on new research as well as on the examination of the two recent discoveries the Authoress casts new light on the issue of mural painting's dating and on the circumstances connected with theirs creation. The article starts with an introduction on pictorial representation and written sources of the legend of Saint Ladislaus. The main part of the text contains survey on the frescoes from Rimabanya, Rakos, Kovi, Szilice.

Keywords: Saint Ladislaus, frescoes, art history, wall paintings

\section{Średniowieczne przedstawienia legendy o św. Władyslawie w komitacie Gomor}

\section{Abstrakt}

Celem artykułu jest szczegółowe przeanalizowanie malowideł przedstawiających legendę o św. Władysławie w komitacie Gomor. Bazując na aktualnych badaniach oraz na dwóch nowych odkryciach, Autorka rzuca nowe światło na kwestie datowania omawianych malowideł oraz okoliczności ich powstania. Artykuł otwiera wprowadzenie na temat ikonografii i źródeł pisanych związanych z legendą o św. Władysławie. Główna część tekstu stanowi analizę fresków z miejscowości Rimbanya, Rakos, Kovi, Szilice.

Słowa kluczowe: św. Władysław, freski, historia sztuki, malowidła ścienne

\section{BIBLIOGRAFIA}

B. Kovács I.: Rimaszombat. Várostörténeti barangolások. I. kötet. Patrióta Kiadó, Rimaszombat. 2010.

Borovszky S.: Borsod vármegye története. MTA., Budapest, 1909.

C. Tóth N.: Luxemburgi Zsigmond uralkodása I387-I437. Kossuth kiadó zRt. 2009.

Csánki D.: Magyarország történeti földrajza a Hunyadiak korában. I. Budapest, I890.

Dénes Gy.: A Bódvaszilasi medence 700 éves története. Borsodi kismonográfiák I6. Herman Ottó Múzeum, Miskolc, 1983.

Dvořáková, V. - Krása, J. - Stejskal, K.: Stredoveká nástenná malba na Slovensku. Praha-Bartislava, 1978.

Engel P.: Magyarország világi archontológiája I3OI-I457 II. kötet, MTA Történettudományi Intézete, Budapest, 1996. 
Fejér, G.: Codex diplomaticus Hungariae ecclesiasticus ac civilis. Tomi VIII. Vol. 4., Budae, I832.

Gerat, I.: Naratívny cyklus zo života sv. Ladislava v ikonografickom programe gemerskych kostolov. Ars I. 1996.

Gomboš, P. - Tajkov, P.: Kostol reformovanej cirkvi v Silici vo svetle najnovších výskumov. In: Východoslovenský pravek X., 2013.

Horváth I.: Szent László kultusza Luxemburgi Zsigmond uralkodói reprezentációjában. In.: (szerk.): Galamb György, Hunyadi Zsolt, AETAS 32. évf. 3., 2017.

Ila B.: Gömör megye. I-IV. Budapest, I944-I976.

Jékely Zs.: A középkori Szent László-falképek másolatai, I863-I9I4. Ars Hungarica 23. 2. I995.

Képes Krónika. A kísérőtanulmányokat Dercsényi Dezső, Kristó Gyula és Csapodiné Gárdonyi Klára írta. Budapest, I986.

Kerny T.: László király szentté avatása és kultuszának kibontakozása (I095-I30I). In: Pócs Éva - Voigt Vilmos (szerk.): Ösök, táltosok, szentek. Budapest, I996.

Kerny T.: László király ikonográfiája. In: Mamül, VI. Budapest, 2006.

Kerny T.: A kerlési ütközet képzőmüvészeti megjelenése és elterjedése. In: Fejös Zoltán (szerk.): Huszka József, a rajzoló gyüjtő. Budapest, 2006.

Kerny T.: A magyar szent királyok tisztelete és ikonográfiája a XIII. századtól a XVII. századig In: Lörincz Tamás (szerk.): Az ezeréves ifjú. Székesfehérvár, 2007.

Kerny T.: A magyar szent királyok tisztelete és ikonográfiája a XIV. század közepéig. In: Kerny Terézia (szerk.): Szent Imre Iooo éve. Székesfehérvár, 2007.

Lángi J.: Ismeretlen Szent László ábrázolások falképeken. In: Barna Gábor (szerk.): A szenttisztelet történeti rétegei és formái Magyarországon és Közép-Európában. A magyar szentek tisztelete. Szeged, 200I.

Lángi J.: Szent László ábrázolásairól. Dolgozatok az Erdélyi Múzeum érem- és régiségtárából. Új sorozat VI-VII. (XVI-XVII.) 2013.

László Gy. - Kerny T.: A Szent László-legenda középkori falképei. Budapest, 1993.

Lukács Zs.: A Szent László-legenda a középkori magyar falképfestészetben. In.: Athleta Patriae. Tanulmányok Szent László történetéhez. Budapest, I980.

M. Kozák É.: Régészeti kutatások a szalonnai református templomban. In.: A Herman Ottó Múzeum Évkönyve 20. Miskolc, I98I.

Marosi E.: A reprezentáció kérdése a I4-I5. századi művészetben. Történelmi Szemle 27. 4., 1984 .

Művészet Zsigmond király korában. Beke L. - Marosi E. - Wehli T. (szerk.): Müvészet Zsigmond király korában. I387-I437. Budapest, I987.

Nagy I.: Magyarország családai czímerekkel és nemzedékrendi táblákkal. Beimel és Kozma, Pest. I857-I868.

Plekanec, V. - Haviar, T.: Gotický Gemer a Malohont. Italianizmy v stredovekej nástennej malbe. Arte Libris, Bratislava. 2007.

Prokopp M.: Italian Trecento Influence on Mural in East-Central Europe, particularly Hungary. Budapest. I98I.

Prokopp M.: Középkori freskók Gömörben. Méry Ratio. Somorja, 2007.

ifj. Reiszig E. dr. - dr. Sarlay S.: Gömör-Kishont vármegye nemes családai. Hermit Kiadó Bt., Budapest. 2012. 
Sigmundus Rex et Imperator. Takács Imre (szerk.): Sigismundus Rex et Imperator. Mủvészet és kultúra Luxemburgi Zsigmond korában, I387-I437. Kiállítási katalógus. Budapest. 2006. Szentpétery, E.: Scriptores rerum Hungaricum tempore ducum regumque stirpis Arpadianae gestarum. Vol. 2., Budapest. 1938.

Togner, M.: Stredoveká nástenná malba v Gemeri. Bratislava 1988.

Togner, M.: Stredoveká nástenná malba na Slovensku. Bratislava, 1988.

Vállal magasb mindeneknél...: A Szent László-herma Győrbe érkezésének 400. évfordulóján megtartott tudományos konferencia előadásai. Székely Zoltán (szerk.), Arrabona. Múzeumi Közlemények 46/I. 2008. 